\title{
Modification and Performance Evaluation of Animal Drawn Onion Seeder
}

\author{
B. Gireesh*, G. Sujatha, B. Sunitha, B. Rajkiran and M.V. Ramana \\ Department of Farm Machinery and Power, College of Agricultural Engineering, Madakasira, \\ Ananthapuram-515 001, Andhra Pradesh, India \\ *Corresponding author
}

\begin{tabular}{|c|c|}
\hline & A B S T R A C T \\
\hline & $\begin{array}{l}\text { Onion (Allium cepa } L \text { ) is the most economical vegetable often used as a spice. The farming } \\
\text { of onion on rainfed areas, by using broad casting method is very difficult. Broadcasting } \\
\text { method results in the higher amount of seed rate, non-uniform distribution of seeds, poor } \\
\text { bulb maturity, higher nutrient competition, and more over it is a time consuming and } \\
\text { laborious process. By taking all these factors into consideration an animal drawn onion } \\
\text { seeder was developed under rainfed onion crop cultivation with a reasonable cost of }\end{array}$ \\
\hline $\begin{array}{l}\text { Ke y w o r d s } \\
\text { Allium cepa } \text { L., } \\
\text { Onion seeder, } \\
\text { Drums, Peg system, } \\
\text { Onion cultivation. }\end{array}$ & $\begin{array}{l}\text { operation. The field area was divided into } 6 \text { no. of plots with length } 20 \mathrm{~m} \text { and width of } 1.6 \\
\text { m. Number of germinated seedlings in a square meter, plant to plant spacing and row to } \\
\text { row spacing were replicated } 5 \text { times in each plot with } 1 / 3^{\text {rd }}, 1 / 2,2 / 3^{\text {rd }} \text { volume of filling in } \\
\text { drums. The number of seedlings/ sq. } \mathrm{m} \text {, in } 1 / 3^{\text {rd }} \text { volume of drum filling with double row } \\
\text { holes ( } 29 \text { ) were more and found to be } 150 \text { number, and single row holes (14) was less and } \\
\text { found to be } 52 \text { number, In plant to plant spacing, } 1 / 2 \text { drum filling single row holes (14) gave }\end{array}$ \\
\hline Article Info & more spacing which was about $10.57 \mathrm{~cm}$ and $1 / 3^{\text {rd }}$ drum filling double row holes (29) gave \\
\hline $\begin{array}{l}\text { Accepted: } \\
23 \text { September } 2017 \\
\text { Available Online: } \\
10 \text { October } 2017\end{array}$ & $\begin{array}{l}\text { holes (14) gave more spacing which was found to be } 11.55 \mathrm{~cm} \text { and with } 1 / 3^{\mathrm{rd}} \text { filling double } \\
\text { row holes }(29) \text { gave less spacing } 6.073 \mathrm{~cm} \text {. The seeder with single row holes open with } 2 / 3 \\
\text { rd of drum filling was selected to drop the onion seed in the rainfed area. The } \\
\text { recommended onion seedlings should be in the range of } 75 \text { to } 80 \text { per sq. } \mathrm{m} \text { with a row to }\end{array}$ \\
\hline & $\begin{array}{l}\text { row spacing of } 7.5 \text { to } 8 \mathrm{~cm} \text { and plant spacing of } 6 \text { to } 8 \mathrm{~cm} \text {. The above recommendations } \\
\text { were met with single row holes (14) opened with } 2 / 3 \text { rd of drum filling. Field capacity of the } \\
\text { seeder with single row holes (14) open and } 2 / 3 \text { rd of drum filling were } 0.32 \mathrm{ha} / \mathrm{hr} \text {. Row to } \\
\text { row spacing was } 7.9 \mathrm{~cm} \text { with germination percentage of } 97.3 \text {. The cost of the developed } \\
\text { animal drawn onion seeder was Rs. } 16,100 \text {. }\end{array}$ \\
\hline
\end{tabular}

\section{Introduction}

Onion (Allium cepa L.) is one of the important commercially cultivated vegetable crops grown throughout India. It is widely grown in different parts of the country mainly by all category of farmers and also consumed worldwide.

India produces about 13 per cent of total worlds production and ranked second after
China. Onion is grown in an area of 1.0 million hectare in India with the production of 15.1 million tonnes over a productivity of 14.2 tonnes/hectare. The important onion growing states are Maharashtra, Bihar, Karnataka, Gujarat, Andhra Pradesh, Orissa and Madhya Pradesh. The total area under onion cultivation in Karnataka is about 1.90 lakh hectares with a production of 2.5 million 
tonnes and productivity of 13.6 tonnes/hectare (Vijay Kumar, 2011).

Onion is an important and indispensable item in every Indian kitchen. As a culinary ingredient it adds to the taste and flavour in a wide range of food preparations. Onion bulbs can be sautéed, grilled, boiled, baked and fried or stuffed. It is used as salad or cooked in various ways in all curries. It is also used in processed forms e.g. flakes, powder paste, pickles etc. It has very good medicinal value and nutritive value. Onion is processed in the form of dehydrated products like flakes, powder, pickles paste, canned and bottled. Processed products of onion are in good demand in local market for defense and fast food industries and also exported to exotic markets to earn valuable foreign exchange (Ramya, 2006).

Thus, there is a steady demand for onions not only in India, but also throughout the world. Onion production might be increased by increasing the area with good variety or by changing the existing management practices. Through improved seed production, both yield and quality can be improved, to fetch higher prices in the market. Therefore, there is a need to increase the supply of quality seed to increase the productivity.

The vegetable cultivation is usually adopted by small and marginal farmers under intensive cropping system. The area under onion cultivation is about 36,842 ha with annual production of about 8,49,000 $\mathrm{mt}$ (BBS, 2007). The national average yield of onion is very low as 6.94 tonne ha-1 while the world average yield is about 20.64 tonne ha- 1 (FAO, 2006). To meet up the demand of increased population, onion production should be increased with lower production cost. Macias et al., (2004) observed that the system of direct seeding obtained better yield (18\%), bulb weight (21\%) and precocity (11 days) in comparison to the transplant methods. In case of rain fed condition, the onion seeds are broadcasted to save the labour and the yield of around 4.5 tonnes ha- 1 was obtained. The poor yield was recorded due to non-uniform spacing of seeds which affected the size of the onion bulbs.

Seed is the basic and crucial input in agricultural production. But the seed quality plays an important role, as the crop yield is directly dependent on seedling emergence and establishment. The quality of seed either for seed production or for general cultivation depends on several factors that influence the planting value of the seeds. Of these, parameters like time of 'harvest, threshing methods and seed moisture have considerable effect on seed quality especially in vegetable crops like onion (Steiner and Akintobi, 1986).

By broadcasting, the seed rate is more, bulb maturity is not good, non-uniformity of spacing and time consumption is more. By considering all these problems, Animal drawn onion seeder was fabricated and onion seeds are broadcasted under rainfed condition.

Broadcasting method reduces the yield \& produce due to non-uniform placement of seeds. Here seed drill is to be preferred for recommended rate of seed and row spacing which helps in intercultural practice. Since the onion seed is of less diameter, more seeds will be dropped in a furrow otherwise pneumatic system has to be developed to convey one/two seed from metering unit to furrow. But the farmers are not able to afford for the pneumatic system because of high initial cost. So farmers feasible seed drill which can place the seeds in furrow, reduces the operation and cultivation cost has to be developed.

By considering all the above factors, an animal drawn onion seeder was developed and evaluated for its performance and percentage germination of seeds was also tested. 


\section{Material and Methods}

\section{Study area}

The experiments were conducted at the Engineering section of Department of Agricultural Engineering at IIHR, Bangalore.

\section{Raw material}

Good quality onion seeds of "Arka Kirthiman" variety was selected. A sample of $260 \mathrm{~g}$ of this variety was used for determining various properties of onion seeds.

\section{Development of an animal drawn onion seeder}

Fig. The CAD Diagram of animal drawn onion seeder was attached on pdf

\section{Design of ground wheel and no. of holes on the drum}

Wheel diameter $=550 \mathrm{~mm}$

Circumference $=\pi \mathrm{d}=3.14 \times 550=1727 \mathrm{~mm}$

For $2 \mathrm{kmph}$ of forward speed, ground wheel makes $=2000 / 17.27=1158$ revolution $/ \mathrm{h}=$ $20 \mathrm{rpm}$

Area covered $=1.6 \times 2000=3200 \mathrm{~m}^{2} / \mathrm{hr}=53.3$ $\mathrm{m}^{2} / \mathrm{min}$

\section{Drum}

Total no. of drums is 14 and each drum diameter is $15 \mathrm{~cm}$. It has 29 holes per each drum. Hole diameter is $3.4 \mathrm{~mm}$ and drum to drum distance $4 \mathrm{~cm}$. No. of holes in the drum is calculated by

$\mathrm{n}=\pi \mathrm{D} / \mathrm{x}$

Where, $\mathrm{n}=$ No. of holes on the drum.

$\mathrm{D}=$ Ground wheel diameter.

$\mathrm{x}=$ Hole to hole spacing.

$\mathrm{D}=55 \mathrm{~cm}$

$\mathrm{x}=6 \mathrm{~cm}$

$\mathrm{n}=\pi \mathrm{D} / \mathrm{x}=3.14 \times 55 / 6$

$\mathrm{n}=28.78$

$\mathrm{n}=29$ holes

Drums were made up of MS discs of $15 \mathrm{~cm}$ diameter \& thickness $8 \mathrm{~mm}$. Fourteen drums of each Drum perimeter $47.1 \mathrm{~cm}$ and diameter $15 \mathrm{~cm}$ were fabricated. It has 29 holes per each drum. In each drum 14 holes (hole to hole distance $3.42 \mathrm{~cm}$ ) in one row and 15 holes (hole to hole distance $3.2 \mathrm{~cm}$ ) in one row as shown in plate 4 . Two M. S discs were separated by spaces in between of length $5 \mathrm{~cm}$. A fiber sheet of length equal to circumference of discs $(4.8 \mathrm{~cm})$, width equal to length of spaces $(6.8 \mathrm{~cm})$ and thickness $4 \mathrm{~mm}$ was selected. The selected fiber sheet was wrapped around and screwed to the two discs.

Drum to drum spacing $4 \mathrm{~cm}$ as shown in fig 1 . The entire assembly is attached in the middle of the frame. In order to rotate the drum, the seeder is pulled in forward direction.

\section{Frame}

It is made of MS hollow square pipe of $2 \times 2$ inch size and $5 \mathrm{~mm}$ thickness. Length and width of frame is $1.95 \mathrm{~m}$ and $38 \mathrm{~cm}$, respectively. Other parts of seeder are fitted with the frame as shown in Figure 2.

\section{Ground wheel}

M.S flat of length $160 \mathrm{~cm}$ and thickness of $5 \mathrm{~mm}$ was selected. Flat was rounded to form a circular wheel of equal dimensions were fitted at either side of shaft of $M$. S the bearings attached to the frame at a distance of $20 \mathrm{~cm}$ to close the dropped seed from the holes of drum. 


\section{Handle}

The seeder has a handle of $2.97 \mathrm{~m}$ length and $28.55 \mathrm{~mm}$ diameter of for easy pulling. It is made of M. S. square pipe used for directing $\&$ guiding the drum seeds.

\section{Pegs}

$12 \mathrm{~mm}$ diameter of M. S square rod was used for making 22 pegs, each peg length $38 \mathrm{~cm}$, peg to peg spacing $6 \mathrm{~cm}$. These pegs were attached to the frame as shown in fig 3. This peg system is groove type adjustable system. To cover the seeds with the soil for improving the seed germination on field.

\section{Shaft}

Two shafts were taken one shaft length is 186 $\mathrm{cm}$ and other shaft length is $22.5 \mathrm{~cm}$, diameter $32 \mathrm{~mm}$ and $28 \mathrm{~mm}$ respectively. It is made up of M.S. rod. To transmit the power ground wheel to the drums. $25 \mathrm{~mm}$, 4 bearings were used for easy rotation and turning purpose.

\section{Fiber sheet}

It is used to closed the gap between 2 drum plates for seed dropping. The seeds dropping purpose, there are 29 holes were made on zig zag (Diagonally) position, in between hole to hole distance is $2.5 \mathrm{~cm}$. The fiber sheet thickness is $4 \mathrm{~mm}$, length is $48 \mathrm{~cm}$ and width is $6.8 \mathrm{~cm}$ for each drum.

\section{Experimental Design}

The experiment was carried out in IIHR at Agricultural engineering section. Experimental field type of soil was red. The field was completely designed into six plots. There were six treatments with each one replication. Site of the each plot was $1.6 \mathrm{~m}$ width and $20 \mathrm{~m}$ length. The different treatments taken up for comparison were
$\mathrm{P}_{1}=$ Single row holes (14holes) with one cup (56.84g).

$\mathrm{P}_{2}=$ Double row holes (29holes) with one cup (56.84g).

$\mathrm{P}_{3}=$ Single row holes (14holes) with two cups (113.68g).

$\mathrm{P}_{4}=$ Double row holes (29holes) with two cups $(113.68 \mathrm{~g})$.

$\mathrm{P}_{5}=$ Single row holes (14holes) with three cups $(170.52 \mathrm{~g})$.

$\mathrm{P}_{6}=$ Double row holes (29holes) with three cups $(170.52 \mathrm{~g})$.

\section{Field preparation}

The field was ploughed using a disk plough, crumbles were broken by spike tooth harrow and leveling was done with help of levelers. The field was laid out in six experimental plots. The plots were allotted for different treatments as shown in Fig 5.

\section{Crop}

The experiment was conducted on refined onion seed crop. The variety of crop is Arka kirthiman was sown in the field. The duration of crop was 120 days. Seed rate was 8-10 $\mathrm{kg} / \mathrm{ha}$. The crop was raised during the early season (October-January) as shown in fig 8.

\section{Results and Discussion}

The results of the present study entitled "Development of an animal drawn onion seeder" conducted at the Section of Agricultural Engineering, Indian Institute of Horticultural Research, Hessaraghatta, Bangalore-560089 and in the Laboratories of IIHR, Bangalore, during the year 2013-2014 are given below. The machine parameters 
were standardized by taking various trials at different no. of holes. The onion sowing machine was analyzed for six field treatments. After field test, 14 holes gave higher germination percentage and plant to plant spacing was $6-8 \mathrm{~cm}$, row to row spacing was $7.5-8 \mathrm{~cm}$.

\section{Development of an animal drawn onion seeder}

The machine parameters were standardized by taking various trials with single row holes (14) and double row holes (29) with $1 / 3^{\mathrm{rd}}, 1 / 2^{\text {th }}$ and $2 / 3^{\text {rd }}$ volume of seed filling in the drums. The onion sowing machine was analyzed for six field treatments.

The machine parameter of $15 \mathrm{~cm}$ diameter drum was standardized. After field test,14 holes with $2 / 3^{\text {rd }}$ of the volume of filling were gave higher germination percentage and plant to plant spacing was $6.5-8 \mathrm{~cm}$, row to row spacing was $7.5-8 \mathrm{~cm}$.

\section{Performance evaluation of developed onion seeder}

The animal drawn onion seeder was evaluated to study the field capacity ha/hr, seedlings in square meter, seed germination per cent age, seed to seed and row to row spacing, $\mathrm{cm}$. The drum has holes in the two rows spaced at a distance of $2.5 \mathrm{~cm}$.

One row has 14 holes and another row has 15 holes. The effect of these holes opening on the density of the crop and germination was determined by filling the drums with $1 / 3^{\mathrm{rd}}, 1 / 2$, $2 / 3^{\text {rd }}$ volume.

\section{Experimental field results}

After sowing the seeds, the seeds were germinated. The seedlings were counted in one square meter per each replication. The counted readings were as shown in the table 2 and a graph in plotted between volume of filling and seedlings/sq.m.

Initially field in divided to six plots. Each plot was of co m length and $1.6 \mathrm{~m}$ width. seeder in tested for no. of plants in $1 \mathrm{~m}^{2}$ area. seeder is operated in the first and second plots with one row of holes open (i.e., 14 holes) and two rows of holes opened (i.e., 29 holes) respectively with $1 / 3$ rd of seed filled in drum.

Seeder was operated in the third and fourth plots with one row of holes open (i.e., 14 holes), another row was closed (i.e., 15 holes) and both rows open (29 holes) respectively with $1 / 2$ of seed filled in drum. Again seeder in operated in the fifth and sixth plots with one row of holes open (14 holes), another row closed (15 holes) and both rows open (29 holes) respectively with $2 / 3^{\text {rd }}$ of seed filled in the drum.

A square meter wooden frame was randomly placed at 5 different places on the germinated seedlings in each plots termed as replication (R1). Five such type replications were taken and recorded in each experimental plot.

From the above graph it in clear that, seeder with two rows opened and with $1 / 3^{\text {rd }}$ of volume of drum filling used good amount of seeds. Which was examined in the second plot compared to the other plots.

An average of seedlings germinated in the second plot $\left(29\right.$ holes open with $1 / 3^{\text {rd }}$ drum filling) was observed as 150 .

\section{Germinated seedlings, row to row spacing (Table 4)}

Since there is no any furrow opener provided to the seedlings there is a chance of spinage and on alignment of seedlings in the row, Hence row to row spacing of the seedlings were also replicated and represent in table 4. 

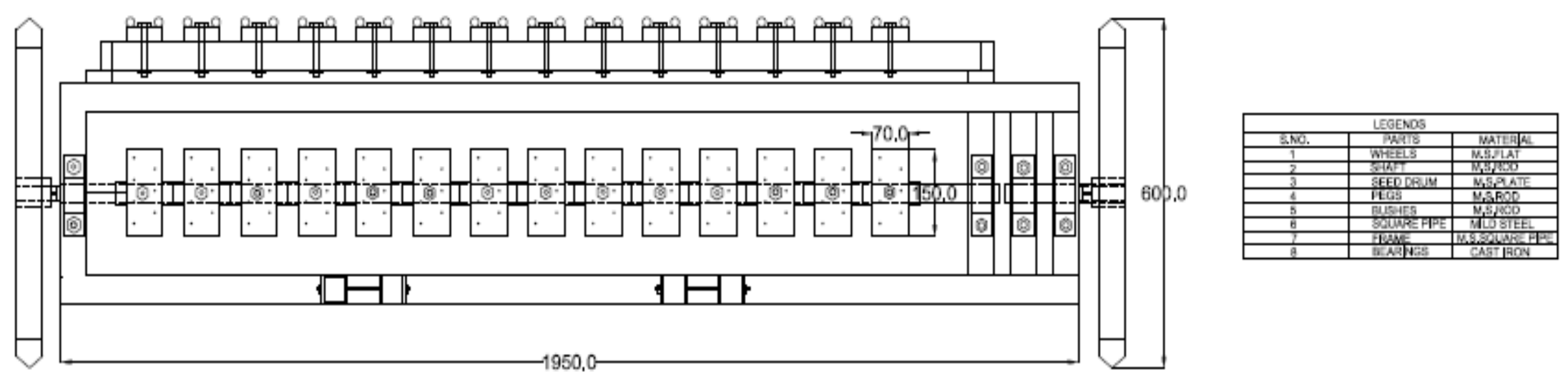

Fig. Top View

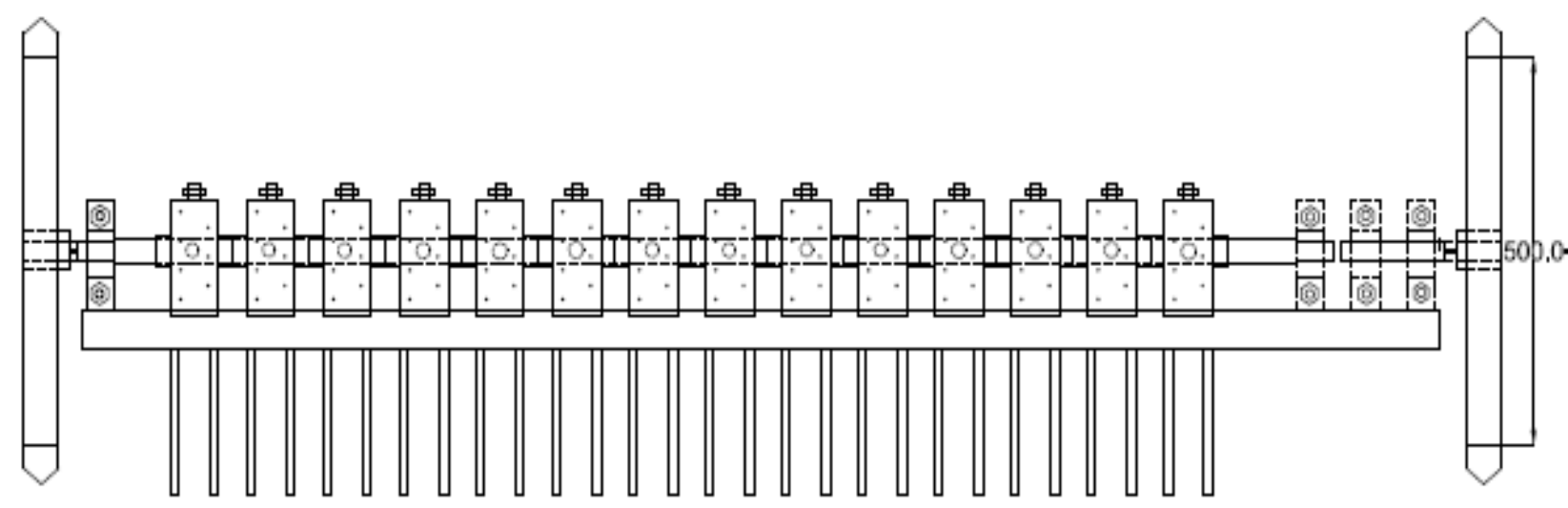

Fig. Front View

Title : Animal drawn onion seeder
All dimensions are in $\mathrm{mm}$ Scale $\cdot 1: 1$

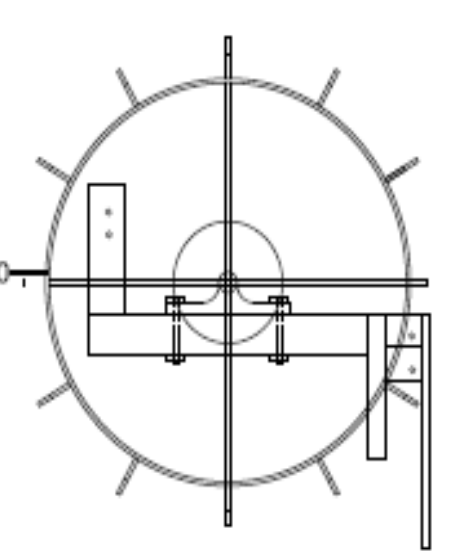

Fig. Side View 
Table.1 Specifications of animal drawn onion seeder

\begin{tabular}{|l|l|}
\hline \multicolumn{2}{|c|}{ Specifications of onion seeder } \\
\hline Description & Onion sowing machine \\
\hline Sources of power & Two bullocks \\
\hline Suitable crop & Onion \\
\hline Principle & Vertical plate mechanism. \\
\hline Onion seeds dia, mm & 3.2 \\
\hline Onion seeds colour & Black \\
\hline No. of drums & $14($ dia $-15 \mathrm{~cm}$, width $-5 \mathrm{~cm})$ \\
\hline Drum to drum distance & $4 \mathrm{~cm}$ \\
\hline No. of holes & 14 \\
\hline Hole dia, mm & 3.4 \\
\hline Plant to plant spacing $(\mathrm{cm})$ & $6.14-8.7$ \\
\hline Row to row spacing $(\mathrm{cm})$ & $7.2-9.15$ \\
\hline Main frame & $195 \times 38(2 \times 2$ inches square pipe $)$ \\
\hline Working width of implement $(\mathrm{cm})$ & 160 \\
\hline Ground wheel diameter(cm) & 50 \\
\hline Field capacity(ha/hr $)$ & 0.32 \\
\hline Cost of machine & Rs. $16,100$. \\
\hline
\end{tabular}

Table.2 Germinated seedlings in one square meter.

\begin{tabular}{|c|c|c|c|c|c|c|}
\hline \multicolumn{7}{|c|}{ Volume of filling } \\
\hline & \multicolumn{2}{|c|}{$1 / 3$} & \multicolumn{2}{|c|}{$1 / 2$} & \multicolumn{2}{|c|}{$2 / 3$} \\
\hline \multicolumn{7}{|c|}{ No. of holes } \\
\hline & $\begin{array}{l}\text { Single } \\
\text { row } \\
\text { holes }(14)\end{array}$ & $\begin{array}{l}\text { Double } \\
\text { row } \\
\text { holes(29) }\end{array}$ & $\begin{array}{l}\text { Single } \\
\text { row } \\
\text { holes(14) }\end{array}$ & \begin{tabular}{|l|} 
Double \\
row \\
holes $(29)$ \\
\end{tabular} & $\begin{array}{l}\text { Single } \\
\text { row } \\
\text { holes }(14)\end{array}$ & $\begin{array}{l}\text { Double } \\
\text { row } \\
\text { holes(29) }\end{array}$ \\
\hline \multicolumn{7}{|l|}{ Seedlings/sq.m } \\
\hline $\mathrm{R} 1$ & 54 & 181 & 52 & 119 & 64 & 115 \\
\hline R2 & 30 & 117 & 50 & 83 & 82 & 111 \\
\hline R3 & 71 & 163 & 48 & 126 & 75 & 126 \\
\hline $\mathrm{R} 4$ & 60 & 151 & 64 & 123 & 89 & 164 \\
\hline R5 & 47 & 140 & 70 & 92 & 89 & 139 \\
\hline Average & 52.4 & 150.4 & 56.8 & 108.6 & 79.8 & 131 \\
\hline $\begin{array}{l}\text { Standard error of } \\
\text { deviation }\end{array}$ & 15.31 & 24.1 & 9.65 & 19.67 & 10.56 & 21.41 \\
\hline $\begin{array}{l}\text { Standard error of } \\
\text { mean }\end{array}$ & 6.85 & 10.77 & 4.31 & 8.79 & 4.72 & 9.57 \\
\hline $\begin{array}{l}95 \% \text { of confidential } \\
\text { limit }\end{array}$ & $\begin{array}{l}38.974 \\
65.826\end{array}$ & $\begin{array}{l}129.29 \\
171.509\end{array}$ & $\begin{array}{l}48.35 \\
65.25\end{array}$ & $\begin{array}{l}91.37 \\
125.83\end{array}$ & $\begin{array}{l}70.55 \\
89.05\end{array}$ & $\begin{array}{l}112.243 \\
149.757\end{array}$ \\
\hline
\end{tabular}


Table.3 Germinated seedlings, plant to plant spacing

\begin{tabular}{|c|c|c|c|c|c|c|c|}
\hline \multicolumn{8}{|c|}{ Volume of filling } \\
\hline & & \multicolumn{2}{|c|}{$1 / 3$} & \multicolumn{2}{|c|}{$1 / 2$} & \multicolumn{2}{|c|}{$2 / 3$} \\
\hline \multicolumn{8}{|c|}{ No. of holes } \\
\hline & & \begin{tabular}{|l} 
Single \\
row \\
holes(14)
\end{tabular} & \begin{tabular}{|l} 
Double \\
row \\
holes(29)
\end{tabular} & \begin{tabular}{|l|} 
Single \\
row \\
holes(14)
\end{tabular} & \begin{tabular}{|l} 
Double \\
row \\
holes(29)
\end{tabular} & \begin{tabular}{|l} 
Single \\
row \\
holes(14)
\end{tabular} & \begin{tabular}{|l} 
Double \\
row \\
holes(29)
\end{tabular} \\
\hline \multirow[t]{6}{*}{$\begin{array}{l}\text { Plant to plant } \\
\text { spacing }(\mathrm{cm})\end{array}$} & & & & & & & \\
\hline & R1 & 6.6 & 4.18 & 14.3 & 8.33 & 8.33 & 6.25 \\
\hline & R2 & 7.46 & 5.00 & 9.56 & 9.08 & 6.14 & 5.88 \\
\hline & R3 & 5.81 & 6.13 & 7.04 & 6.73 & 7.21 & 5.88 \\
\hline & R4 & 10.875 & \begin{tabular}{|l|}
6.78 \\
\end{tabular} & 9.45 & 6.25 & 8.33 & 6.67 \\
\hline & R5 & 9.54 & \begin{tabular}{|l}
$\mid 4.7$ \\
\end{tabular} & 12.5 & 7.69 & 8.33 & \begin{tabular}{|l|l|}
6.67 &
\end{tabular} \\
\hline \multicolumn{2}{|l|}{ Average } & 8.057 & 5.358 & 10.57 & 7.616 & 7.668 & 6.67 \\
\hline \multicolumn{2}{|c|}{$\begin{array}{lll}\begin{array}{l}\text { Standard } \\
\text { deviation }\end{array} & \text { error } & \text { of }\end{array}$} & 2.1 & \begin{tabular}{|l|}
1.07 \\
\end{tabular} & 2.84 & 1.15 & 0.98 & 0.395 \\
\hline \multicolumn{2}{|c|}{$\begin{array}{l}\text { Standard error of } \\
\text { mean }\end{array}$} & 0.94 & \begin{tabular}{|l|}
0.48 \\
\end{tabular} & 1.27 & 0.514 & 0.438 & 0.176 \\
\hline \multicolumn{2}{|c|}{$\begin{array}{l}95 \% \text { of confidential } \\
\text { limit }\end{array}$} & $\begin{array}{l}6.215 \\
9.89\end{array}$ & \begin{tabular}{|l|}
4.417 \\
6.298 \\
\end{tabular} & \begin{tabular}{|l|}
8.085 \\
13.059
\end{tabular} & $\begin{array}{l}6.609 \\
8.617\end{array}$ & \begin{tabular}{|l|}
6.81 \\
8.526
\end{tabular} & $\begin{array}{l}6.325 \\
7.015\end{array}$ \\
\hline
\end{tabular}

Table.4 Germinated seedlings, row to row spacing

\begin{tabular}{|c|c|c|c|c|c|c|c|}
\hline \multicolumn{8}{|c|}{ Volume of filling } \\
\hline & & \multicolumn{2}{|l|}{$1 / 3$} & \multicolumn{2}{|c|}{$1 / 2$} & \multicolumn{2}{|c|}{$2 / 3$} \\
\hline \multicolumn{8}{|c|}{ No. of holes } \\
\hline & & $\begin{array}{l}\text { Single } \\
\text { row } \\
\text { holes(14) }\end{array}$ & \begin{tabular}{|l} 
Double \\
row \\
holes(29)
\end{tabular} & $\begin{array}{l}\text { Single } \\
\text { row } \\
\text { holes }(14)\end{array}$ & $\begin{array}{l}\text { Double } \\
\text { row } \\
\text { holes(29) }\end{array}$ & $\begin{array}{l}\text { Single } \\
\text { row } \\
\text { holes }(14)\end{array}$ & $\begin{array}{l}\text { Double } \\
\text { row } \\
\text { holes }(29)\end{array}$ \\
\hline \multicolumn{8}{|l|}{$\begin{array}{l}\text { Row to row } \\
\text { spacing }(\mathrm{cm})\end{array}$} \\
\hline & R1 & 7.54 & 4.895 & 16.67 & 8.33 & 7.14 & 9.09 \\
\hline & R2 & 7.23 & 5.47 & 9.75 & 9.09 & 7.53 & 7.5 \\
\hline & R3 & 7.91 & 7.46 & 14.00 & 7.15 & 10.00 & 7.69 \\
\hline & R4 & 8.04 & 5.88 & 8.00 & 9.09 & 7.38 & 7.31 \\
\hline & R5 & 9.00 & 6.67 & 9.33 & 6.2 & 7.69 & 7.14 \\
\hline \multicolumn{2}{|l|}{ Average } & 7.944 & 6.073 & 11.55 & 7.97 & 7.972 & 7.746 \\
\hline \multicolumn{2}{|c|}{$\begin{array}{l}\text { Standard error of } \\
\text { deviation }\end{array}$} & 0.67 & 1.01 & 3.65 & 1.27 & 1.16 & 0.78 \\
\hline \multicolumn{2}{|c|}{ Standard error of mean } & 0.3 & 0.451 & 1.63 & 0.567 & 0.518 & 0.35 \\
\hline \multicolumn{2}{|c|}{$95 \%$ of confidential limit } & $\begin{array}{l}7.356 \\
8.532\end{array}$ & $\begin{array}{l}5.189 \\
6.976\end{array}$ & $\begin{array}{l}8.355 \\
14.745\end{array}$ & $\begin{array}{l}6.859 \\
9.081\end{array}$ & $\begin{array}{l}6.957 \\
8.987\end{array}$ & $\begin{array}{l}7.06 \\
8.432\end{array}$ \\
\hline
\end{tabular}


Table.5 Specifications and cost of developed animal drawn onion seeder

\begin{tabular}{|l|l|l|l|l|}
\hline $\begin{array}{l}\text { Sl. } \\
\text { No. }\end{array}$ & Material & Size & Quantity & $\begin{array}{l}\text { Total cost of } \\
\text { materials (Rs) }\end{array}$ \\
\hline 1. & Mild steel Frame & $1950 \times 380 \times 5 \mathrm{~mm}$ & $10 \mathrm{~kg}$ & 600 \\
\hline 2. & Mild steel Shaft & $\begin{array}{l}1860 \times 32 \mathrm{~mm} \\
225 \times 32 \mathrm{~mm}\end{array}$ & $\begin{array}{l}1 \mathrm{No} \\
1 \mathrm{No}\end{array}$ & 600 \\
\hline 3. & Mild steel bush & $\begin{array}{l}20 \times 35 \mathrm{~mm} \\
75 \times 50 \mathrm{~mm}\end{array}$ & $\begin{array}{l}28 \mathrm{No} \\
2 \mathrm{No}\end{array}$ & 240 \\
\hline 4. & $\begin{array}{l}\text { Mild steel Ground } \\
\text { wheel }\end{array}$ & $1570 \times 500 \times 5 \mathrm{~mm}$ & $2 \mathrm{No}$ & 1800 \\
\hline 5. & Drums & $150 \mathrm{~mm} \varnothing$ & $14 \mathrm{No}$ & 2100 \\
\hline 6. & Fiber sheet & $471 \times 70 \mathrm{~mm}$ & $14 \mathrm{No}$ & 4600 \\
\hline 7. & Mild steel square pipes & $100^{\prime}$ & $2 \mathrm{No}$ & 1000 \\
\hline 8. & Mild steel pegs & $380 \times 12 \mathrm{~mm}$ & $28 \mathrm{No}$ & 300 \\
\hline 9. & Mild steel spacer & $50 \times 40 \mathrm{~mm}$ & $14 \mathrm{No}$ & 280 \\
\hline 10. & MS-angle & $1700 \times 25 \times 5 \mathrm{~mm}$ & $4 \mathrm{~kg}$ & 300 \\
\hline 11. & Bearings & $25 \mathrm{~mm}$ & 4 No & 1000 \\
\hline 12. & Plastic caps & $20 \times 30 \varnothing \mathrm{mm}$ & 14 No & 280 \\
\hline 13. & $\begin{array}{l}\text { Bolts, nuts and } \\
\text { miscellaneous }\end{array}$ & $6,8,10,12 \mathrm{~mm}$ & - & 500 \\
\hline Total cost & & - & 13,600 \\
\hline Labour cost & & - & 2500 \\
\hline Total cost of machine & & & $\mathbf{1 6 , 1 0 0}$ \\
\hline
\end{tabular}

Fig.1 Drums
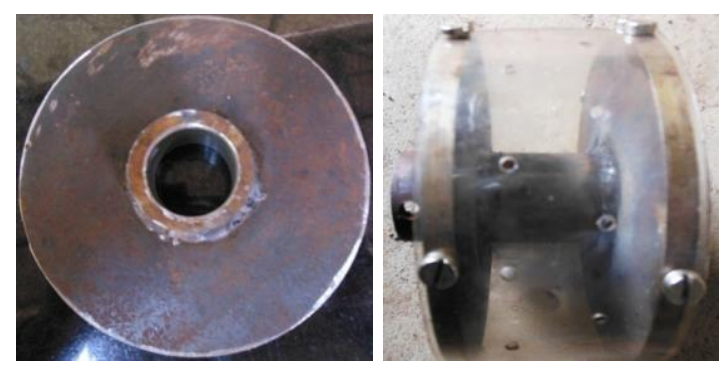

Fig.2 Frame

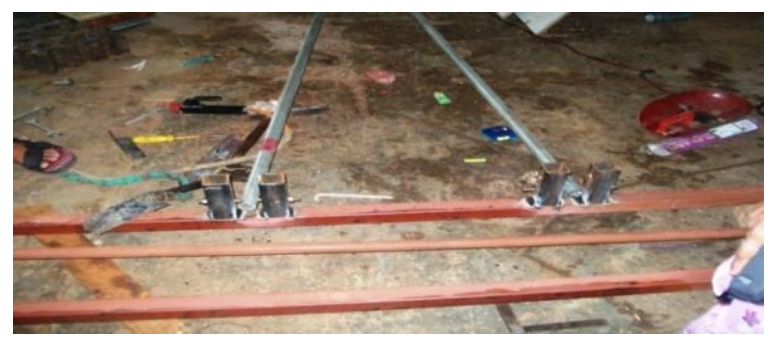


Fig.3 Peg system

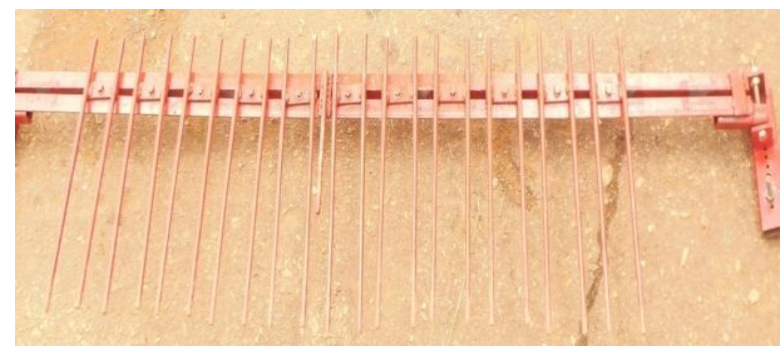

Fig.4 Animal drawn onion seeder front, top and side views

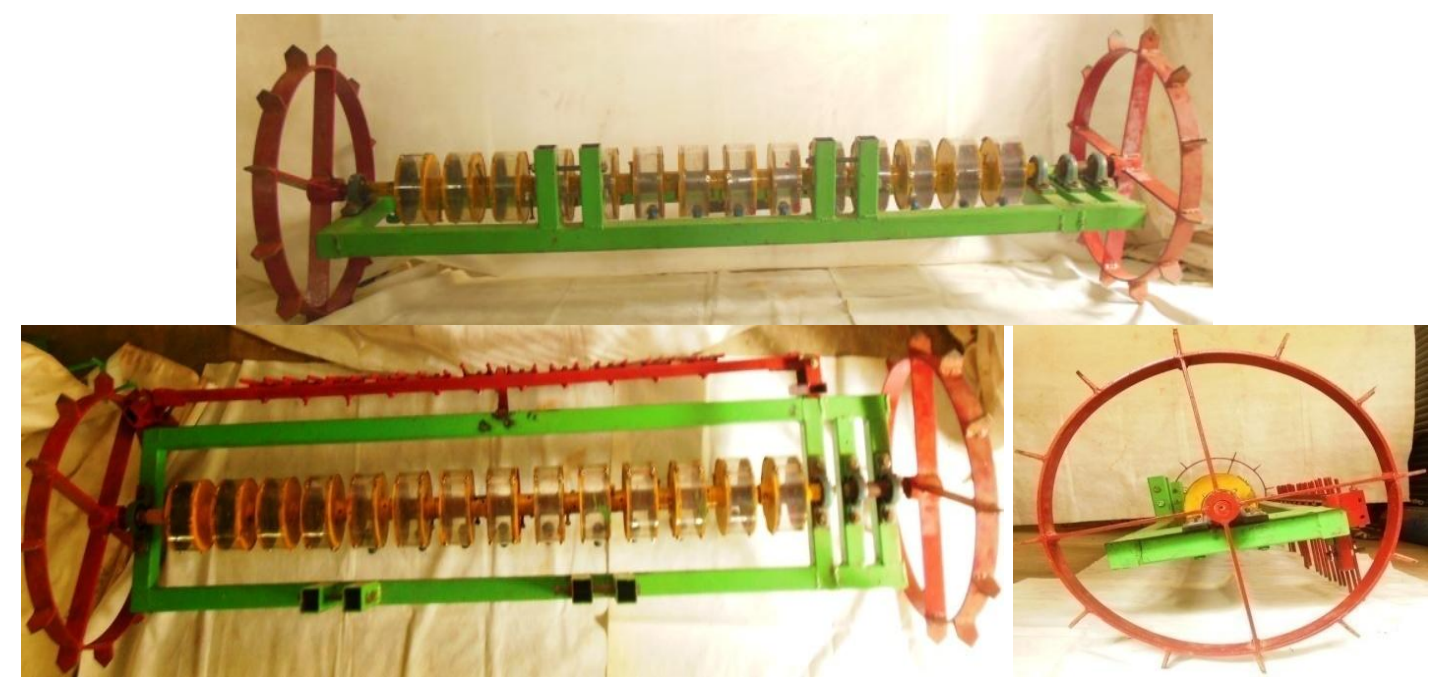

Fig.5 Field layout plan

\begin{tabular}{|c|c|c|c|c|c|}
\hline & & \multicolumn{4}{|c|}{ Volume of filling } \\
\hline \multicolumn{2}{|c|}{$1 / 3($ single cup $)$} & \multicolumn{2}{|c|}{$1 / 2$ (two cups) } & \multicolumn{2}{|r|}{$2 / 3$ (three cups) } \\
\hline Plot1 & Plot2 & Plot3 & Plot4 & Plot5 & Plot6 \\
\hline $\begin{array}{c}\text { Single row } \\
\text { holes(14holes) }\end{array}$ & $\begin{array}{c}\text { Double row } \\
\text { holes(29holes) }\end{array}$ & $\begin{array}{c}\text { Single row } \\
\text { holes(14holes) }\end{array}$ & $\begin{array}{c}\text { Double row } \\
\text { holes(29holes) }\end{array}$ & $\begin{array}{c}\text { Single row } \\
\text { holes(14holes) }\end{array}$ & $\begin{array}{r}\text { Double row } \\
\text { holes(29holes }\end{array}$ \\
\hline$\cdot \cdot \cdot \cdot \cdot$ & . . & · & - & . & $\cdot$ \\
\hline.$\quad$. & 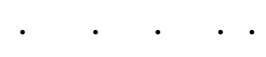 & . & . . & . & . \\
\hline $20 \mathrm{~m}$ &.$\quad$. & . & . & . & . \\
\hline$\cdot \quad \cdot \quad \cdot$ & $\cdot \quad \cdot$ & . & . & . & . \\
\hline$\underset{\longmapsto}{\cdot} \cdot \cdot \cdot \cdot \cdot$ & . . & . & . & . & . \\
\hline
\end{tabular}


Fig.6 Field layout

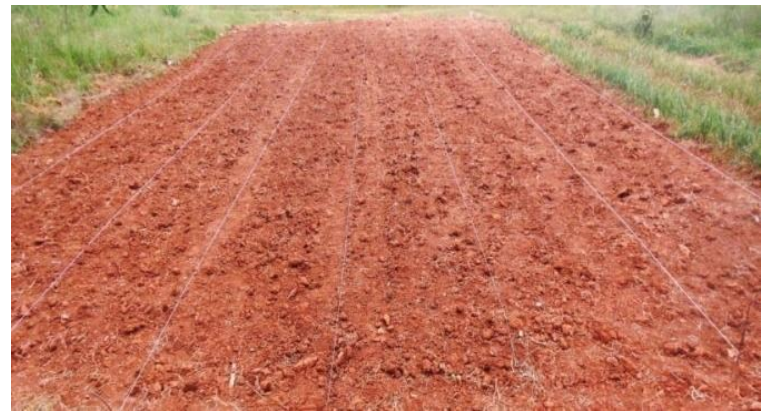

Fig.7 Weeding in plots

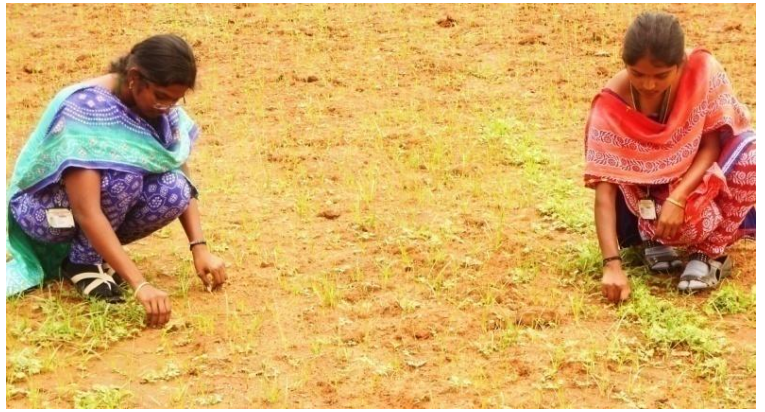

Fig.8 Onion crop in laid plot

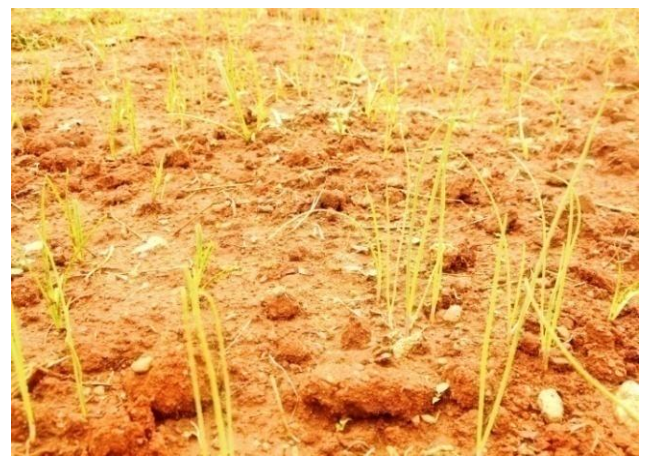

Fig.9 Seedlings per square meter for replications

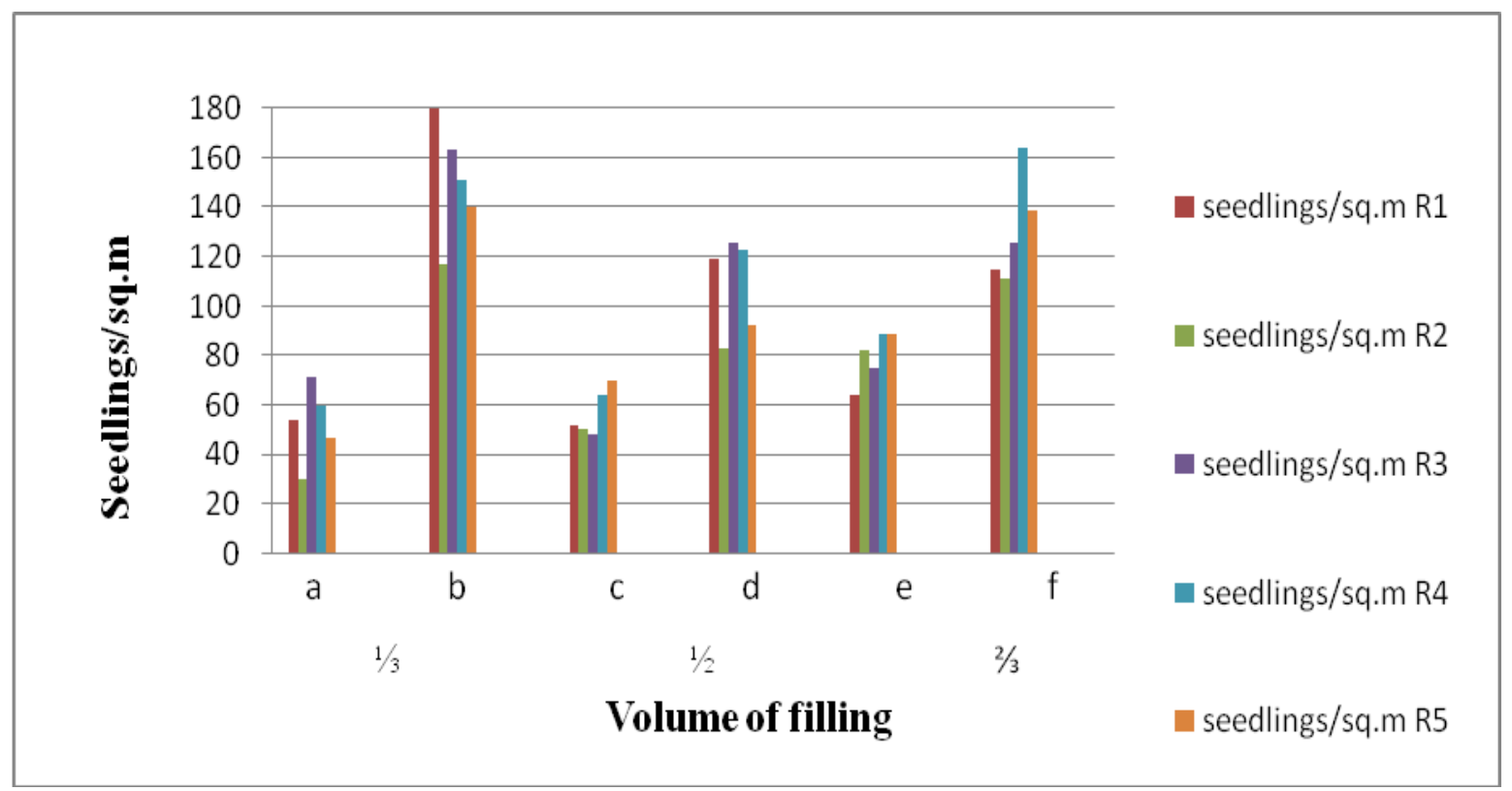

a. Sowing with one row (14) when $1 / 3^{\text {rd }}$ of drum is filled, b. Sowing with two rows (29) when $1 / 3^{\text {rd }}$ of drum is filled c. Sowing with one row (14) when $1 / 2$ of drum is filled, $\mathbf{d}$. Sowing with two rows (29) when $1 / 2$ of drum is filled e. Sowing with one row (14) when $2 / 3^{\text {rd }}$ of drum is filled, f. Sowing with two row (29) when $2 / 3^{\text {rd }}$ of drum is filled 
Fig.10 Average values of seedlings per square meter for replications

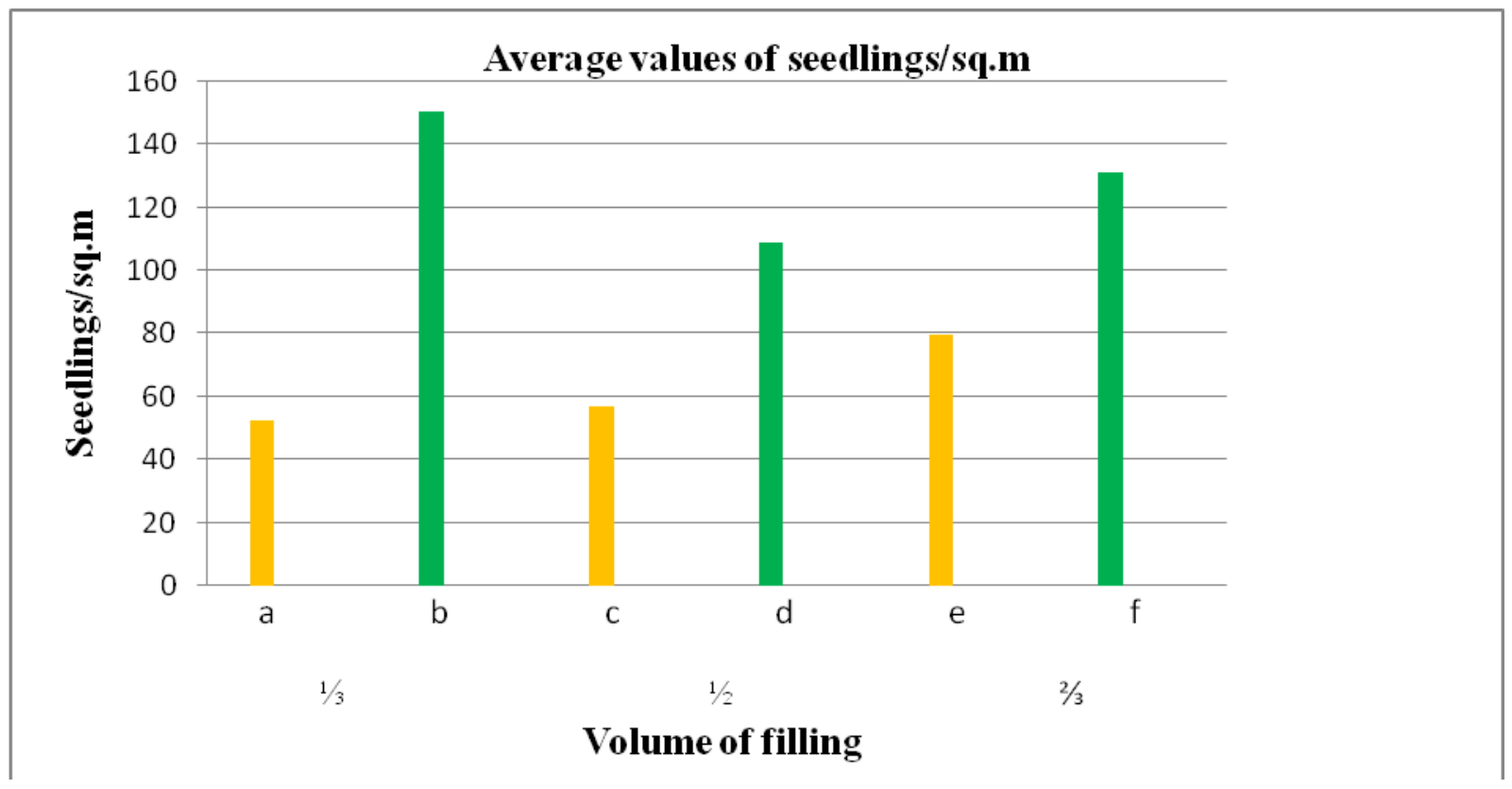

a. Sowing with one row (14) when $1 / 3^{\text {rd }}$ of drum is filled, b. Sowing with two rows (29) when $1 / 3^{\text {rd }}$ of drum is filled

c. Sowing with one row (14) when $1 / 2$ of drum is filled, $d$. Sowing with two rows (29) when $1 / 2$ of drum is filled

e. Sowing with one row (14) when $2 / 3^{\text {rd }}$ of drum is filled, f. Sowing with two row (29) when $2 / 3^{\text {rd }}$ of drum is filled

Fig.11 Plant to plant spacing for replications

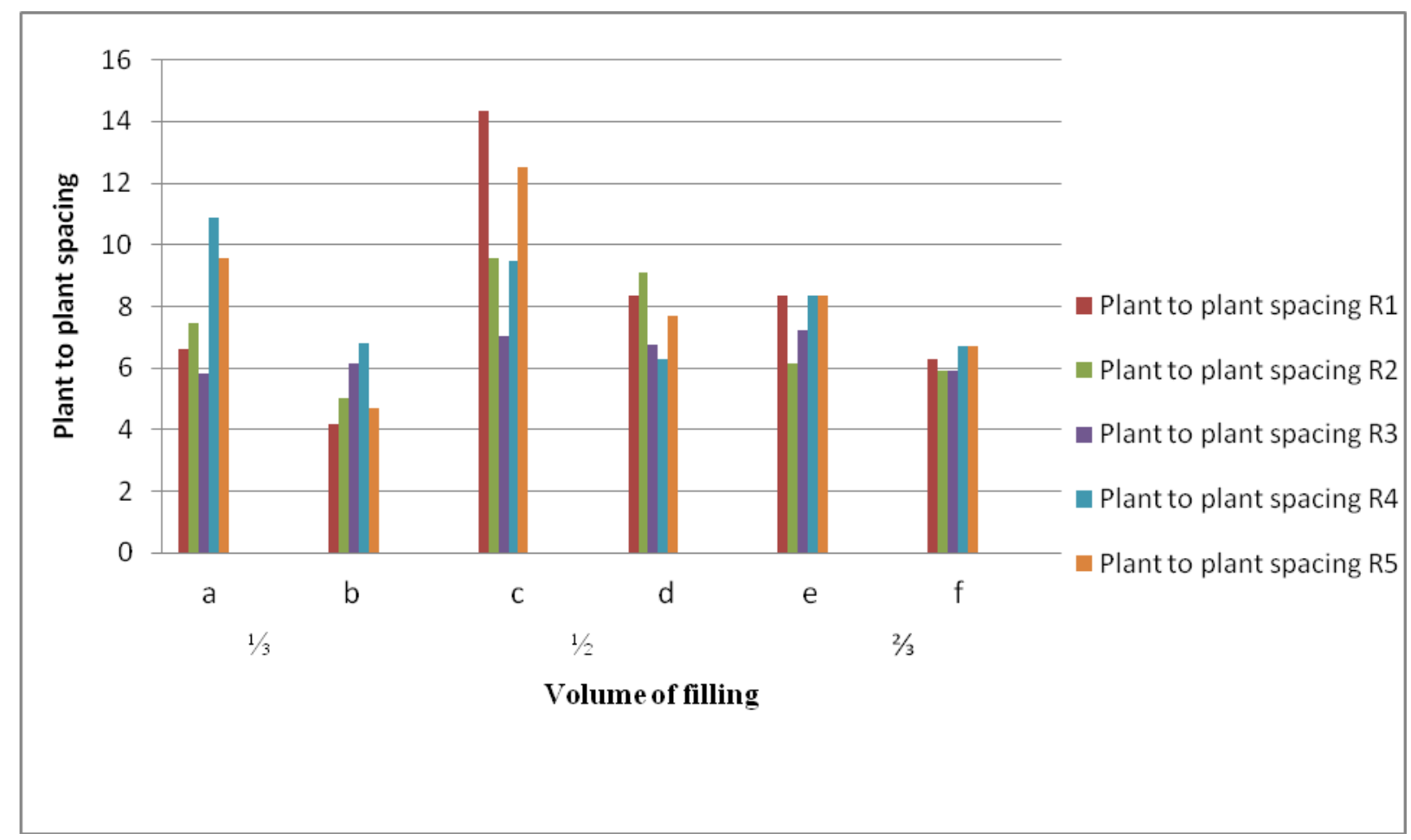


Fig.12 Average values of plant to plant spacing

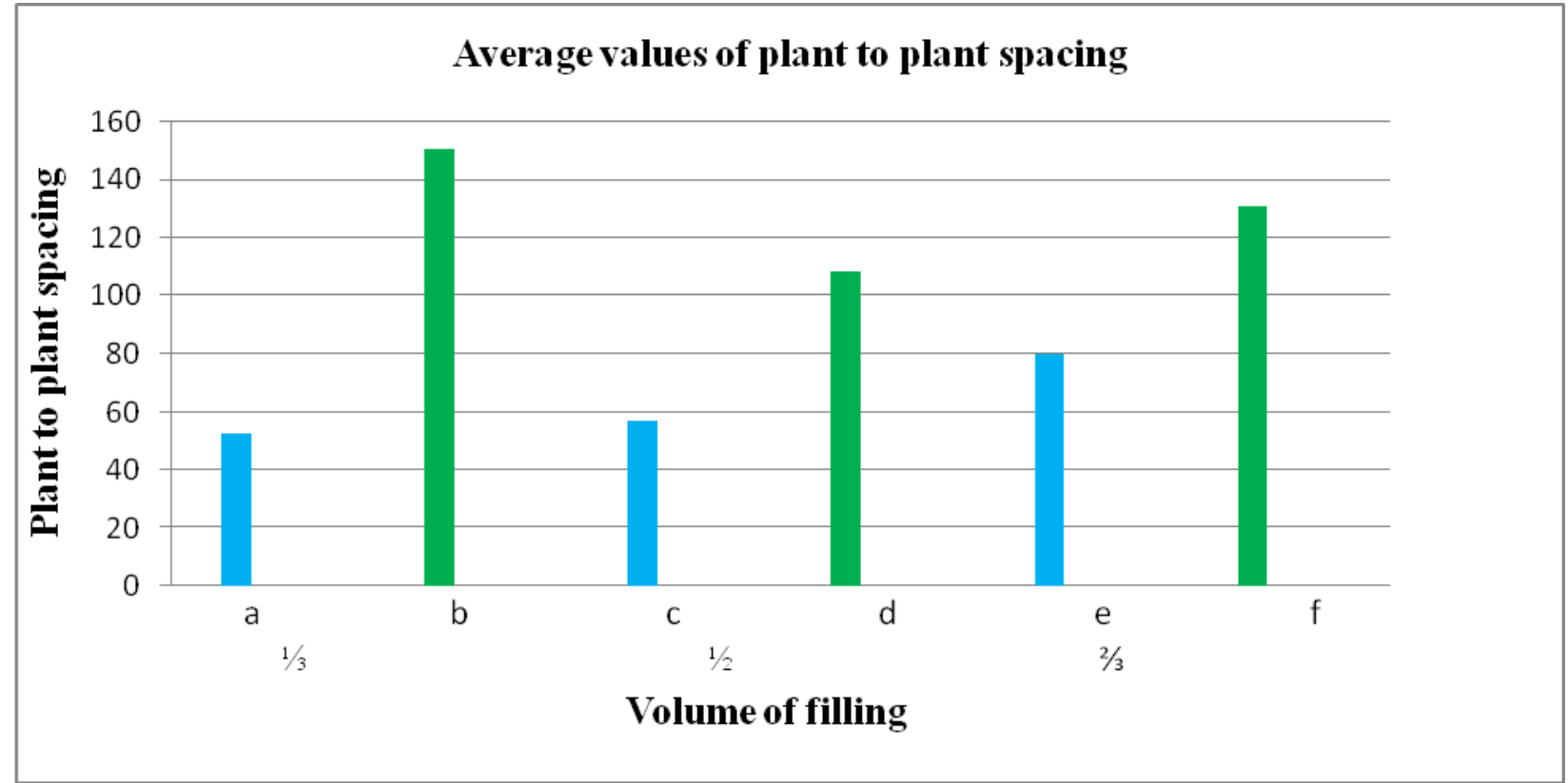

a. Sowing with one row (14) when $1 / 3^{\text {rd }}$ of drum is filled, b. Sowing with two rows (29) when $1 / 3^{\text {rd }}$ of drum is filled

c. Sowing with one row (14) when $1 / 2$ of drum is filled, d. Sowing with two rows (29) when $1 / 2$ of drum is filled

e. Sowing with one row (14) when $2 / 3^{\text {rd }}$ of drum is filled, f. Sowing with two row (29) when $2 / 3^{\text {rd }}$ of drum is filled

Fig.13 Row to row spacing for five replications

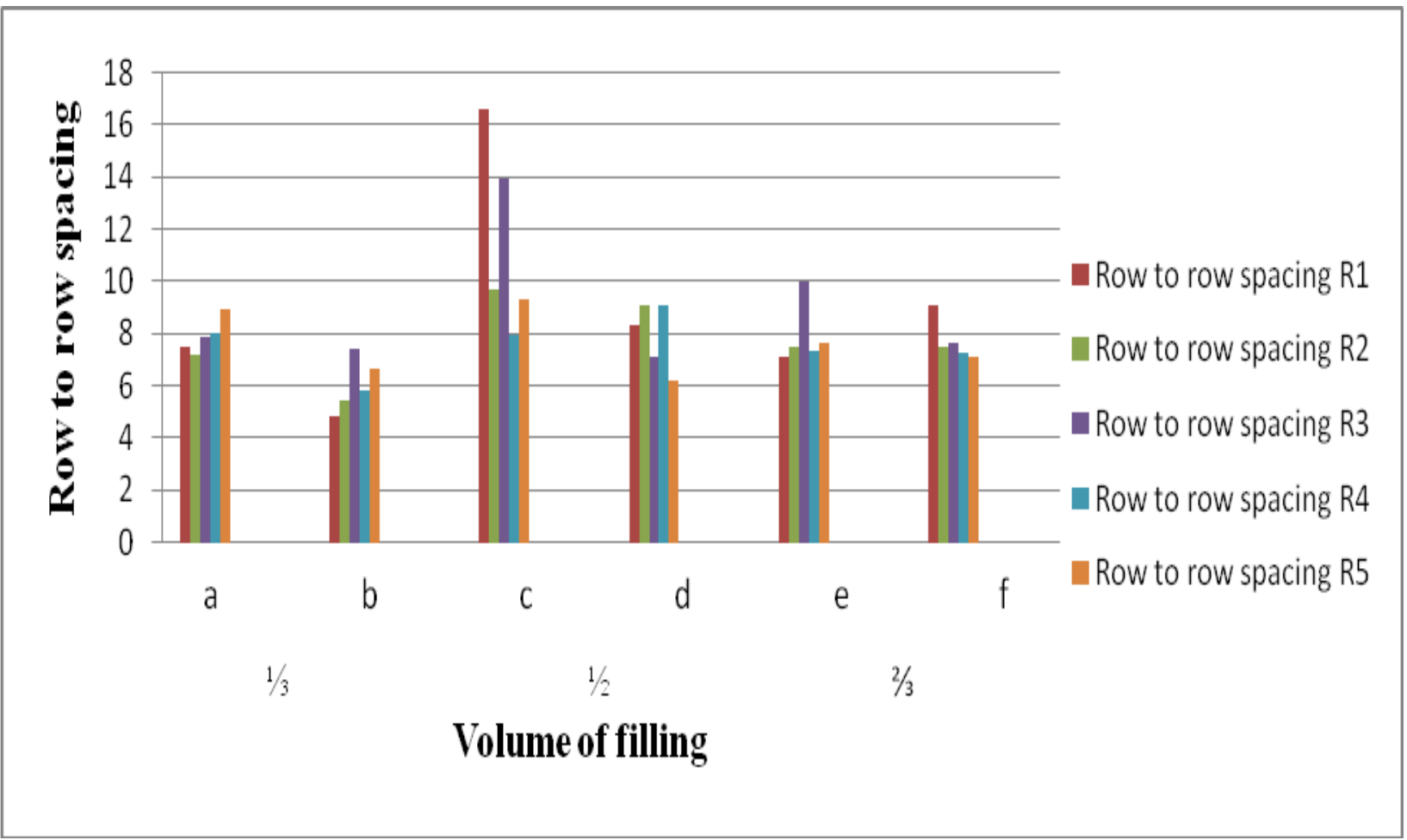


Fig.14 Average values of row to row spacing

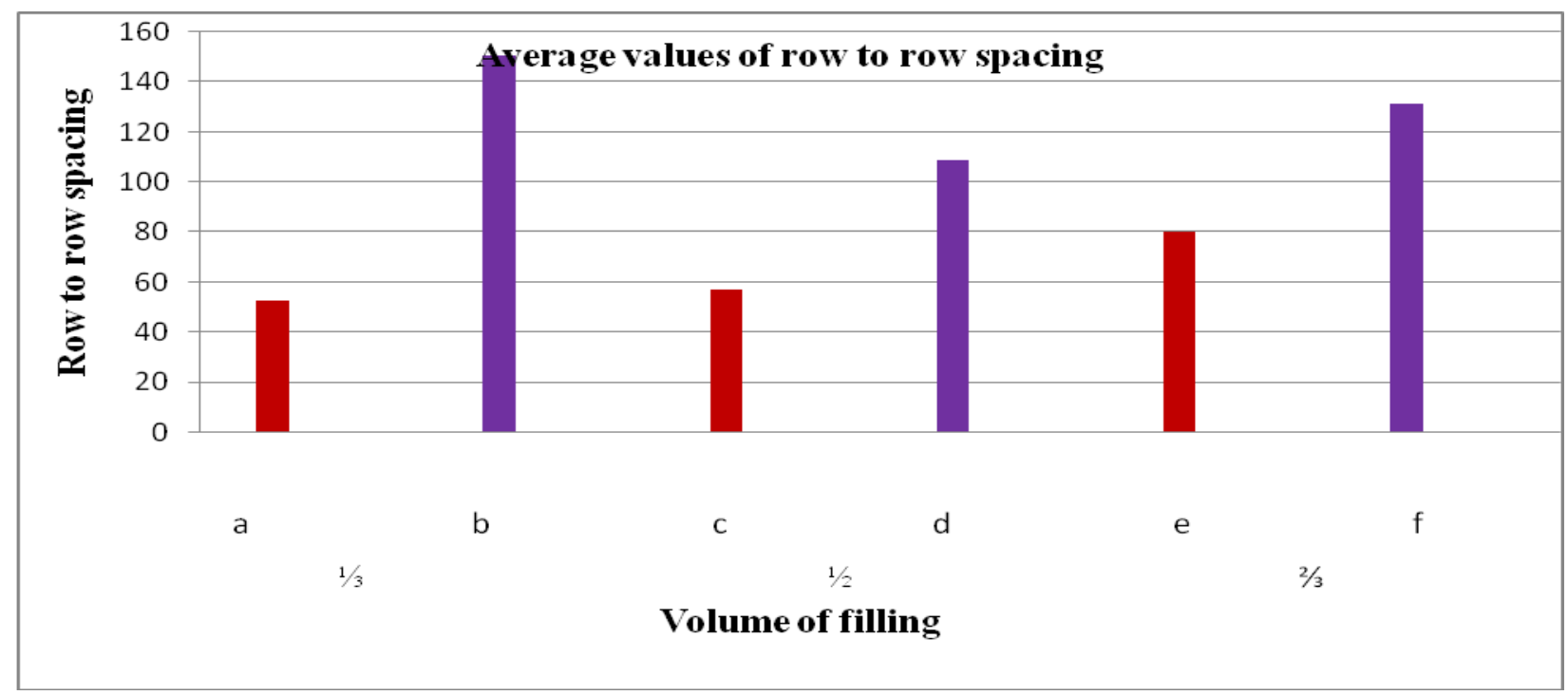

\section{Cost economics}

The economics of the developed seeder and the cost incurred to sowing the seeds were determined taking into account the fixed cost, it includes Material cost, Fabrication cost and Salvage value and Variable costs, is includes Labour cost. The total cost of the machine was Rs. 16, 100. It is shown in table 5. Developed animal drawn onion seeder consists of two ground wheels of diameter $50 \mathrm{~cm}, 14$ no. of drums provided with 29 no. of holes mounted on the rotating shaft. The entire attachment was fixed on the frame.

One wheel rotates the metering unit (14 drums) and another wheel is independent which helps in turning the machine. 28 no. of pegs were welded to the frame to assist in covering the dropped seeds. Total length of the machine 1.95 $\mathrm{m}$ and width is $38 \mathrm{~cm}$. Physical and mechanical properties of onion seeds such as geometric mean diameter, sphericity, bulk density, true density, co-efficient of static friction determined by various methods.

The developed animal drawn onion seeder was field tested in red soil in the experimental plot at IIHR, Bangalore. The field area was divided into 6 no. of plots with length $20 \mathrm{~m}$ and width of $1.6 \mathrm{~m}$. No. of germinated seedlings in a square meter, plant to plant spacing and row to row spacing were replicated 5 times in each plot with $1 / 3^{\mathrm{rd}}, 1 / 2,23^{\mathrm{rd}}$ volume of filling in drums.

In no. of seedlings/sq.m, $1 / 3^{\text {rd }}$ double row holes (29) is more (150 no.) and single row holes (14) is less (52). In plant to plant spacing, $1 / 2$ filling single row holes gives more spacing $(10.57 \mathrm{~cm})$ and $1 / 3^{\text {rd }}$ double row holes (29) gives less spacing $(5.358 \mathrm{~cm})$. In row to row spacing, $1 / 2$ filling single row holes gives more spacing $(11.55 \mathrm{~cm})$ and $1 / 3^{\text {rd }}$ double row holes (29) gives less spacing $(6.073 \mathrm{~cm})$.

The seeder with single row holes open with $2 / 3{ }^{\mathrm{rd}}$ of drum filling was selected to drop the onion seed in the rainfed area. The recommended onion seedlings should be in the range of 75 to 80 per sq.m with a row spacing of 7.5 to $8 \mathrm{~cm}$ and plant spacing of 6 to $8 \mathrm{~cm}$. The above recommendation was alignment with single row holes (14) opened with $2 / 3$ rd of drum filling.

Field capacity of the seeder with single row holes (14) open and $2 / 3$ rd of drum filling were $0.32 \mathrm{ha} / \mathrm{hr}$. Row to row spacing was $7.9 \mathrm{~cm}$ with a germination per centage of $97.3 \%$. The cost of the animal drawn onion seeder was Rs. 16,100 Cost Economics of Animal Drawn Onion Seeder 


\section{Fixed cost}

a. Material cost + Fabrication cost $(C)=$ Rs. 16,100

b. Salvage value (S) @ 10\% of total cost machine $=$ Rs. 1610

\section{Operational cost}

a. Annual use (U) (Expected operational hours) $=720 \mathrm{~h}$

b. Expected life years $(\mathrm{L})=10$ years

\section{Fixed cost}

Depreciation (D)

$\mathrm{D}=\frac{\mathrm{C}-\mathrm{S}}{\mathrm{UL}}=\mathrm{Rs} \cdot 2 \cdot 01 / \mathrm{h}$

Interest on capital investment @ $12 \%$ per annum on average price (I)

$I=\frac{C+S}{2 U} \times 0.12=$ Rs. $0.295 / h$

Repairs/maintenance cost @ $2 \%(\mathrm{R})$

$\mathrm{R}=\frac{\mathrm{C}}{\mathrm{UL}} \times 0.02=$ Rs. $0.045 / \mathrm{h}$

Total fixed cost $(\mathrm{D}+\mathrm{I}+\mathrm{R})=\mathrm{Rs} \cdot 2.35 / \mathrm{h}$

\section{Operational cost/Variable cost}

Labour cost @ ₹ 250 per day (8 hours) per person or Rs. $31.25 / \mathrm{h}$

Total variable cost $(\mathrm{b})=$ Rs. $31.25 / \mathrm{h}$
Total cost of operation $(\mathrm{A})=$ Total fixed cost + Total variable cost $=$ Rs $(2.35+31.25) / \mathrm{h}=$ Rs. $33.6 / \mathrm{h}$

\section{References}

Hoque, M.A., and Wohab M.A., 2013. Development \& evaluation of a drum seeder for onion, Int.J.Agril.res.Innov. \& Tech 3(1): 26 - 28.

Meijer, E.C.N., 1985. New Appearances of Seeds and Direct Drilling Technics for Onions, ISHS Acta Horticulturae 187: I International Symposium on Mechanization of Vegetable Production.

Ramya, M., 2006. Studies on male sterility, harvest and threshing methods on seed quality in onion (Allium cepa L.). Ph. D. thesis, (Unpublished) University of agricultural sciences, Bangalore.

Steiner, J. J., and Akintobi D. C., 1986. Effect of harvest maturity on viability of onion seeds, Hort. Sci., 21: 1220-1221.

Vejasit, A., and Salokhe, V. 2004. Studies on Machine-crop Parameters of an axial flow thresher for threshing soybean. Agriculture Engineering International, the GIGR Journal of Scientific Research and Development, Manuscript PM 04004.

Vijaya rani sharma, T. R., and Narendra singh, 2002. Testing and evaluation of vegetable seed extractor for brinjal (Solanum melongena). Horticultural science haryana agricultural university journal of research, 30: 1/2, 19-24.

Yilmaz, D., Akinci, I. and Cagirgan, M.I. 2008. Effect of some threshing parameters on sesame separation. Agricultural Engineering International, the CIGR Ejournal, Manuscript PM 08.004. X.

\section{How to cite this article:}

Gireesh, B., G. Sujatha, B. Sunitha, B. Rajkiran and Ramana, M.V. 2017. Modification and Performance Evaluation of Animal Drawn Onion Seeder. Int.J.Curr.Microbiol.App.Sci. 6(10): 2749-2763. doi: https://doi.org/10.20546/ijcmas.2017.610.323 